\title{
Research on development strategy and risk prevention of Chinese film industry
}

\author{
Xiancai Zhang \\ School of Communication, Yunnan Normal University \\ Kunming 650500, China \\ 1073479599@qq.com
}

\begin{abstract}
With the improvement of people's spiritual requirements, the film gets more and more people's favorite, and the film industry continues to develop.At present, the film innovation is insufficient, the film quality is not high;Film industry policy management and industry standards are not perfect; The incomplete industrial chain of China's big film industry is the current plight of China's film industry. The combination of the strategies formulated according to these difficulties and the risk prevention strategies in investment, policy and market can promote the better development of the film industry.
\end{abstract}

Keywords-The film industry;Development strategies;Risk prevention

With the development of economy, people's economic income and living standards have been improved, and the requirements for spiritual life have also been raised. As the seventh art, film enriches people's material and spiritual world and becomes an important part of people's leisure and entertainment. People's demand for film products is increasing and the film industry is developing continuously. As a kind of cultural industry, film industry can not only bring economic benefits, but also promote people's cultural and social changes.

\section{THE DEVELOPMENT STATUS OF CHINESE FILM INDUSTRY}

\section{A. The rise of China's film industry}

At present, the production, number of screens and box office of Chinese film industry are all on the rise. First of all, as a core part of the film industry, film production in China has maintained sufficient vitality. According to statistics from the state administration of radio, film and television (sarft), from the mid-1990s to the early 2000s, the production of domestic feature films averaged around 80-90 a year. In order to encourage the production of domestic films, the country has relaxed some policies. In 2005, the number of domestic films reached 260, and then the number rose all the way to 1,082 by 2018 .The film screen is the window of the film, showing the film to the audience, the increase of the number of screens is also an important condition for the development of the film industry. The number of screens in China reached 2,668 in 2005 and 6,079 in 2018.In 2010, China's annual box office exceeded 10 billion yuan. In 2018, the national box office reached 60.976 billion yuan, among which the domestic box office reached 37.897 billion yuan, accounting for $62.15 \%$ of the total box office. On the whole, with the continuous growth of the total box office, the number of domestic films is also increasing year by year. Except for 2012, the share of domestic films in the total box office exceeds that of imported films, which reflects the dominant position of domestic films in the local market.

\section{B. The importance of developing the film industry}

The development of the film industry can realize multiple economic, social and cultural values and provide more people with opportunities to enjoy art. According to historical materialism, the economic foundation determines the superstructure, which reflects and reacts on the economic foundation [1]. The film industry develops on the basis of continuous economic development and material improvement. Movies enrich people's material and spiritual life, and can improve people's awareness and civilization while spreading. The film industry is a large industrial chain. Its production and production process requires the cooperation of multiple departments such as literature, photography and editing, and its development will promote the mutual development of multiple industries. In a word, the development of film and television industry will not only bring economic value added, but also promote people's cultural and social changes.

\section{THE PLIGHT OF CHINA'S FILM INDUSTRY}

Since the reform and opening up, the state has been increasingly supporting the film industry. A series of preferential policies have been introduced in tax policies, credit financing and other aspects, providing a solid economic foundation for the development of the film industry. At the same time, people's demand for films is increasing due to the increasing income and great work pressure. Obviously, China's film industry has made remarkable achievements in recent years, but we should also note that China's film industry is also facing great difficulties.

\section{A. Film innovation is insufficient, quality needs to be improved}

With the continuous increase of film production in China, the film types in China are becoming more and more rich and popular with more audiences. Film production is an important condition for the film industry, but relative to the quantity, the benefit and quality of film is the key to the development of industrial film.

At present, the quality of Chinese films needs to be improved urgently. As far as technology is concerned, when making some sci-fi movies, this gap will be reflected, but technology is not the most important thing. A good story is the key to the success of a film. Theoretically speaking, as a big cultural country, China has many stories to explore and many cultural elements to apply, but in reality, we have not seen so many excellent Chinese films. On the one hand, the 
level of our scriptwriters and directors needs to be improved. More importantly, due to the lack of innovation in Chinese films, the homogenization of Chinese films is serious. For a long time, Hollywood movies have exerted a subtle influence on Chinese audiences' taste and habit of watching movies, making directors cater to the audience for commercial effects and fail to get rid of the shadow of Hollywood.

\section{B. Copyright law protection is not perfect}

At present, China's film industry policy management and industry norms are not perfect, including the film copyright legal protection. As a copyright product, film has high initial cost and low reproduction cost. Compared with the relatively perfect copyright law protection in the United States, Japan, South Korea and other countries, the copyright law protection of Chinese films is not standardized, and film products can even be obtained at low or no cost. This is the film industry management and industry standards are not perfect performance, but also lead to the corresponding loss of funds.

\section{The big film industry chain needs to be improved}

In the mature film industry, box office revenue accounts for only a small part of the total profit. In China, box office revenue is the biggest source of revenue for the Chinese film industry. Compared with Hollywood's complete film industry chain, China's film industry chain has great room for improvement. In a series of industrial chains, such as TV, Internet, audio and video, publishing, toys and tourism, video online paying users are increasing, and movies are an important consumption content. In addition, there are also a few films that can achieve certain success in one of the links of the film industry chain. For example, the animated film "bear" series released a series of toys, and the movie "from all over the world" boosted the tourism industry of daocheng. However, generally speaking, China's film industry chain is not sound, and few films can achieve success in the whole industry chain. After all, only a few films can make profits in some links of the industry chain.

\section{THE BASIC COUNTERMEASURES FOR THE DEVELOPMENT OF CHINESE FILM INDUSTRY}

To develop China's film industry, the author believes that it is necessary to constantly improve the ability of film innovation, improve copyright law protection and improve the industrial chain of large films.

\section{A. Improving film innovation ability}

Jiang zemin pointed out that "innovation is the soul of a nation's progress, the inexhaustible power of a country's prosperity, and the source of a political party's eternal vitality" [2]. The rapid rise of China's film industry has attracted worldwide attention. The Chinese government's support for films has also been strengthened. The film industry should seize this opportunity to accelerate reform and innovation to improve the quality of films. Some films take high box office as their primary purpose at the beginning of creation, putting more energy on marketing and promotion rather than paying attention to the quality of films themselves. However, the success of a film is rooted in the high level of creation. If technology and culture are integrated and innovated, the localization level of Chinese films can be improved. Culture is the spiritual charm of a film, a film with cultural value is beneficial to the spread and development of culture. We believe that we can create more excellent films and promote the development of film art. Today's movie audiences are young people, they more hope to be able to see different work, constantly imitation will can't meet the needs of the audience, many mining and production of innovative films, and enhance innovation capability, increase the diversity of Chinese film and cultural charm, as well as improve the quality of the film can meet the demand of the audience's viewing.

\section{B. Improving copyright legal protection}

We will improve policy management and industry standards for China's film industry. First of all, in terms of policies and laws, more detailed provisions should be made on the copyright protection of film products, and the corresponding legal provisions should introduce a more perfect punishment system for ACTS such as infringement and piracy. In addition, the audience should consciously respect the copyright of film products, improve the copyright awareness, and resist the copying, distribution, screening and other activities suspected of infringement. In addition, at present, there are fans on the Internet who make unauthorized modifications to the film works to gain commercial benefits, which infringes on the interests of producers, directors, photographers and other authors. Audiences should learn more about copyright knowledge in their daily life to promote the better and faster development of the film industry.

\section{Improve the film industry chain}

The big film industry chain here includes a series of post-film product development in addition to the small films composed of film production, distribution and projection. Chen shuo divided post-film and television products into two categories: post-product with film and television as the core and film-oriented derivative development.[3] In China's current situation, in the post-product development with films as the core, the relevant systems such as online paid films and overseas copyright sales have been relatively mature, and the production and distribution of DVD, VCD and other audio-visual products are relatively few. In the movie-oriented derivative development, there is still a long way to go for the development of Chinese films. No matter for daily necessities, main parks or tourism development, a good development mode has not been formed. We can appropriately learn from the relatively perfect post-film product development mode of Japan and the United States, and at the same time, highlight the localization and national culture of China in the film, which is beneficial to the development of more post-film products.

\section{RISK PREVENTION STRATEGIES FOR CHINA'S FILM INDUSTRY}

In addition to formulating specific strategies according to difficulties, the development of the film industry should also improve its awareness of risk prevention and formulate specific risk prevention strategies. For a long time, the film industry has been an industry with high risks and high profits. In the process of investment, production, distribution and reflection, films will be affected by many risk factors. In the process of investment, we should first base ourselves on the local market and develop the domestic market. China itself is a huge market with huge potential. The development of the local market is the fundamental to accelerate the development of the film industry [4]. Only make full use of the influence of Chinese culture to enter the Chinese culture 
market and the European and American markets. Policy risks are also one of the risks faced by the film industry. Due to the great spreading power of films, films should pay close attention to national political factors and basic legal changes. The development of the film industry should not only pursue economic interests. As the product of the development of science and technology, the content of science and technology is very important to the development of film industry. Under the Internet age, new media and new technology are born. To develop in the long run, the film industry must be closely combined with science and technology and keep pace with The Times. In addition, the film industry will face a variety of market risks. The film industry should have the correct positioning, accurately grasp the audience acceptance, and at the same time avoid the chaotic scene of competition with peers or homogenization of business.

\section{A. Improving film innovation ability}

Jiang zemin pointed out that "innovation is the soul of a nation's progress, the inexhaustible power of a country's prosperity, and the source of a political party's eternal vitality" [2]. The rapid rise of China's film industry has attracted worldwide attention. The Chinese government's support for films has also been strengthened. The film industry should seize this opportunity to accelerate reform and innovation to improve the quality of films. Some films take high box office as their primary purpose at the beginning of creation, putting more energy on marketing and promotion rather than paying attention to the quality of films themselves. However, the success of a film is rooted in the high level of creation. If technology and culture are integrated and innovated, the localization level of Chinese films can be improved. Culture is the spiritual charm of a film, a film with cultural value is beneficial to the spread and development of culture. We believe that we can create more excellent films and promote the development of film art. Today's movie audiences are young people, they more hope to be able to see different work, constantly imitation will can't meet the needs of the audience, many mining and production of innovative films, and enhance innovation capability, increase the diversity of Chinese film and cultural charm, as well as improve the quality of the film can meet the demand of the audience's viewing.

\section{B. Improving copyright legal protection}

We will improve policy management and industry standards for China's film industry. First of all, in terms of policies and laws, more detailed provisions should be made on the copyright protection of film products, and the corresponding legal provisions should introduce a more perfect punishment system for ACTS such as infringement and piracy. In addition, the audience should consciously respect the copyright of film products, improve the copyright awareness, and resist the copying, distribution, screening and other activities suspected of infringement. In addition, at present, there are fans on the Internet who make unauthorized modifications to the film works to gain commercial benefits, which infringes on the interests of producers, directors, photographers and other authors. Audiences should learn more about copyright knowledge in their daily life to promote the better and faster development of the film industry.

\section{Improve the film industry chain}

The big film industry chain here includes a series of post-film product development in addition to the small films composed of film production, distribution and projection. Chen shuo divided post-film and television products into two categories: post-product with film and television as the core and film-oriented derivative development.[3] In China's current situation, in the post-product development with films as the core, the relevant systems such as online paid films and overseas copyright sales have been relatively mature, and the production and distribution of DVD, VCD and other audio-visual products are relatively few. In the movie-oriented derivative development, there is still a long way to go for the development of Chinese films. No matter for daily necessities, main parks or tourism development, a good development mode has not been formed. We can appropriately learn from the relatively perfect post-film product development mode of Japan and the United States, and at the same time, highlight the localization and national culture of China in the film, which is beneficial to the development of more post-film products.

\section{China's film industry risk prevention strategy}

In addition to formulating specific strategies according to difficulties, the development of the film industry should also improve its awareness of risk prevention and formulate specific risk prevention strategies. For a long time, the film industry has been an industry with high risks and high profits. In the process of investment, production, distribution and reflection, films will be affected by many risk factors. In the process of investment, we should first base ourselves on the local market and develop the domestic market. China itself is a huge market with huge potential. The development of the local market is the fundamental to accelerate the development of the film industry [4]. Only make full use of the influence of Chinese culture to enter the Chinese culture market and the European and American markets. Policy risks are also one of the risks faced by the film industry. Due to the great spreading power of films, films should pay close attention to national political factors and basic legal changes. The development of the film industry should not only pursue economic interests. As the product of the development of science and technology, the content of science and technology is very important to the development of film industry. Under the Internet age, new media and new technology are born. To develop in the long run, the film industry must be closely combined with science and technology and keep pace with The Times. In addition, the film industry will face a variety of market risks. The film industry should have the correct positioning, accurately grasp the audience acceptance, and at the same time avoid the chaotic scene of competition with peers or homogenization of business.

\section{REFERENCES}

[1] Jia-xiang zhao.Economic basis determines the formation process and systematic demonstration of superstructure principle.Journal of Beijing university of administration, 2011(01) : 57.

[2] Xia dongmin.On jiang zemin's innovation concept.Journal of suzhou university (philosophy and social science edition), 2005(1):12.

[3] Chen ruo.Research on the development of post-film products in China. Kaifeng: henan university, 2010.

[4] Peng zhubin, liu ling. Basic strategies for preventing investment risks in China's film industry. Film art,2006(05):104-105. 